\title{
МЕТОД ОПРЕДЕЛЕНИЯ АКТИВНОСТИ ПРОСТАГЛАНДИН-СИНТЕТАЗЫ В СЕМЕННЫХ ПУЗЫРЬКАХ БАРАНОВ
}

По разработанной в нашей лаборатории препаративной технологии биосинтеза простагландинов (ПГ) путем биохимической окислительной циклизации арахидоновой кислоты в качестве исходного сырья для получения энзимных препаратов используют семенные пузырьки баранов (СПБ) [1]. Содержание ПГ-синтетазы в СПБ зависит от условий сбора и хранения СПБ. Следует отметить, что качество СПБ, собранных на разных мясокомбинатах, колеблется в широких пределах. Следовательно, и энзимные препараты, полученные по стандартной технологии, различаются по активности, что, в свою очередь, приводит к непостоянству выхода целевого продукта в биосинтезе.

В настоящей работе изложен быстрый и удобный метод оценки качества СПБ путем определения активности ПГ-синтетазы в стандартном энзимном препарате (гомогенате).

\section{Методика}

Определение активности ПГ-синтетазы в СПБ проводили при помощи кислородного электрода гальванического типа [ $\left.{ }^{2}\right]$ при температуре $30 \pm 0,02^{\circ} \mathrm{C}$. В реактор с рабочим объемом 4,4 м вводили 5 м $0,05 \mathrm{M}$ трис- или ӘДТА-буфера (рH 8,5) и интенсивно перемешивали на магнитной мешалке в течение 10 мин. Затем реактор закрывали кислородным электродом. Через боковую трубку микрошприцами вводили в реактор 8 мкл раствора арахидоновой кислоты в этаноле и по 30 мкл водных растворов фенола (Ph) и восстановленного глутатиона (GSH), концентрации которых в реакторе составляли 50 мкM, 0,7 $\mu M$ и 3,0 мM соответственно. Реакцию инициировали добавлением 10 мкл энзимного препарата $\left([\mathrm{E}]_{0}=55\right.$ мка белка на 1 мл). Энзимные препараты хранили при температуре $0^{\circ}$ и использовали для полярографических измерений в течение 1 \%. Концентрацию белка определяли методом Лоури [3]. Субстрат, выделенный из липидов по методике, разработанной в нашей лаборатории [4], перед употреблением очищали от продуктов автоокисления при помощи колоночной хроматографии на силикагеле.

\section{Обсуждение результатов}

При биохимическом превращении полиеновых жирных кислот в ПГ с участием комплекса энзимов - ПГ-синтетаза - лишь в первой стадии, катализируемой ПГ-эндопероксид-синтетазой или диоксигеназой 


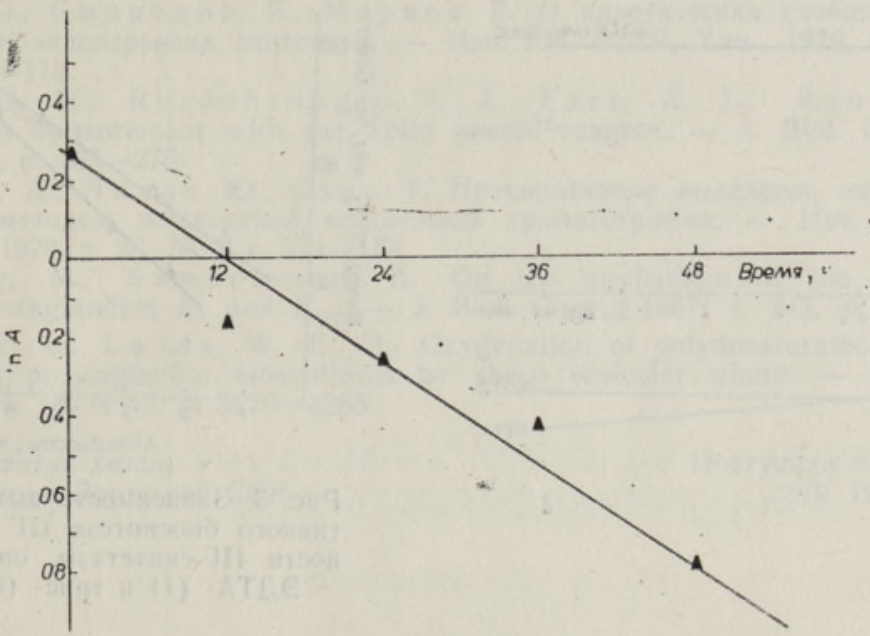

Рис. 1. Уменьшение активности (A) ПГ-синтетазы в виде гомогената СПБ при температуре хранения $0{ }^{\circ} \mathrm{C}$.

происходит окисление субстрата растворенным в реакционной среде кислородом [5]. Таким образом, кинетическая кривая поглощения кислорода в измерительной ячейке кислородного электрода характеризует ход образования ПГ-эндоперекисей - ПГ $G$ и $H$. Ранее доказано, что

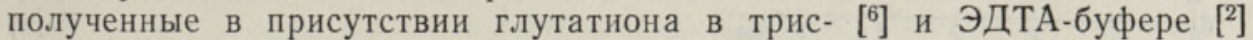
данные поглощения кислорода полностью соответствуют действительному выходу образующегося ПГ $E_{2}$. Это позволяет судить о выходе ПГ $E_{2}$ в биосинтезе по значениям поглощения кислорода, в расчете 2 моля $\mathrm{O}_{2}$ на 1 моль субстрата.

При длительном хранении энзимных препаратов в виде гомогената происходит значительное понижение активности ПГ-синтетазы. Например, гомогенат, оставленный на 2 сут при температуре $0^{\circ}$, сохраняет $35 \%$ начальной активности (рис. 1). Поэтому энзимные препараты в виде гомогената ткани СПБ пригодны для кинетических измерений лишь в течение нескольких часов.

Характер кинетических кривых поглощения кислорода при использовании неочищенных энзимных препаратов в значительной степени зависит от последовательности добавления реагентов [ $\left.{ }^{2}\right]$. Так как скорость реакции при инициировании энзимом в нашем случае почти на $70 \%$ выше чем при инициировании субстратом, для практического определения целесообразнее пользоваться первым вариантом.

Опытами без введения субстрата установлено, что одновременно с окислительной циклизацией арахидоновой кислоты имеет место поглощение кислорода энзимным препаратом (рис. $2 a$ ). Для обоих буферов этот эффект примерно одинаков и объясняется окислением эндогенных липидов в неочищенном энзимном препарате. Кроме того при использовании трис-буфера необходимо учитывать поглощение кислорода восстановленным глутатионом в присутствии арахидоновой кислоты без добавления энзима. Это выражается линейным дрейфом нулевой линии, начинающимся по истечении первой минуты с момента введения арахидоновой кислоты (рис. 2б). Следует отметить, что описанный эффект в ЭДТА-буфере не наблюдается. 

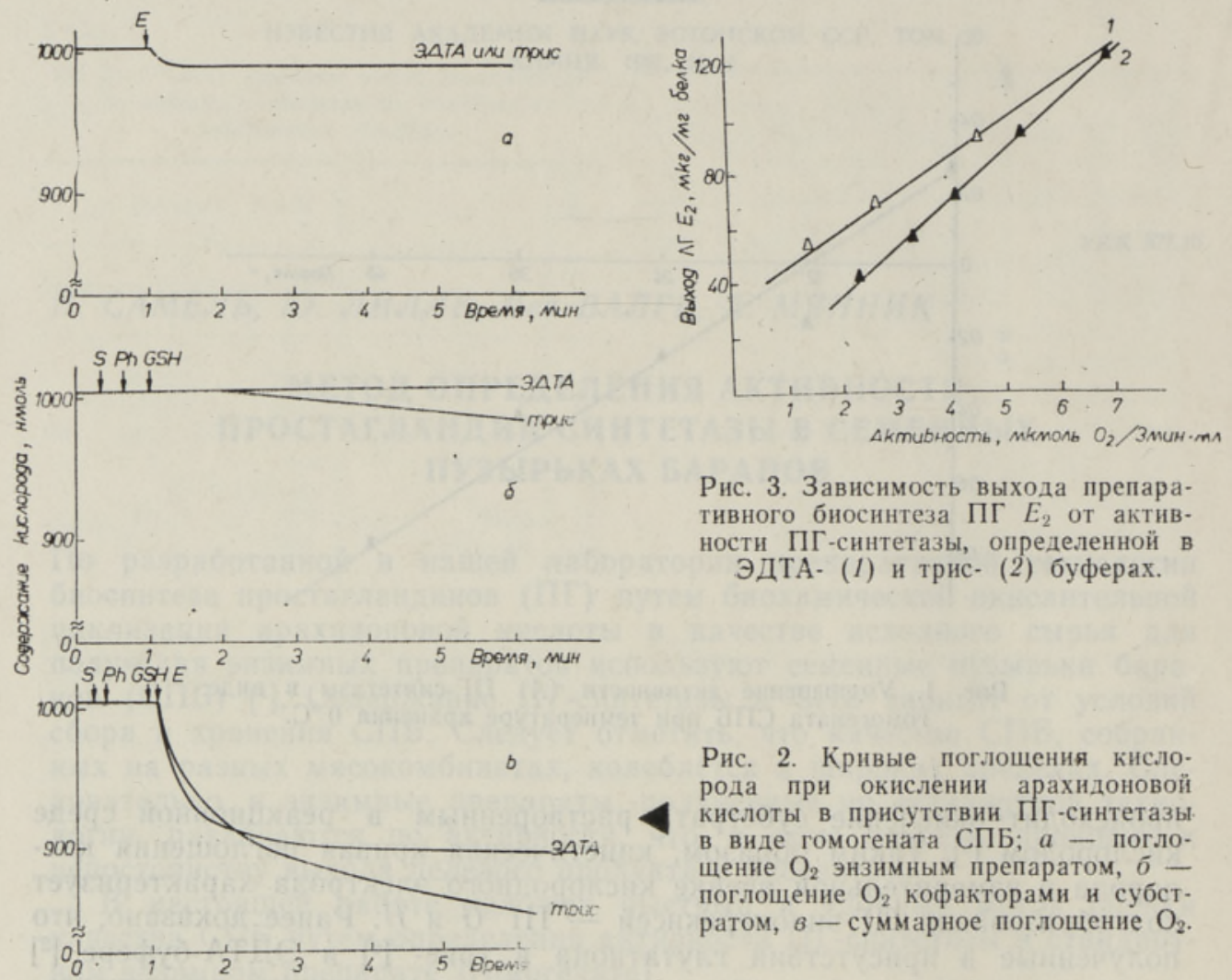

Рис. 3. Зависимость выхода препаративного биосинтеза ПГ $E_{2}$ от активности ПГ-синтетазы, определенной в ЭДТА- (I) и трис- (2) буферах.

Рис. 2. Кривые поглощения кислорода при окислении арахидоновой кислоты в присутствии ПГ-синтетазы в виде гомогената СПБ; $a$ - поглощение $\mathrm{O}_{2}$ энзимным препаратом, бпоглощение $\mathrm{O}_{2}$ кофакторами и субстратом, 8 - суммарное поглощение $\mathrm{O}_{2}$.

Для получения значений поглощения кислорода, действительно характерных биохимическому окислению арахидоновой кислоты в данный момент времени, необходимо в количественные значения суммарного поглощения кислорода (рис. 28) ввести соответствующие поправки.

Определение начальной скорости реакции в таких условиях неудобно и весьма неточно, величиной активности ПГ-синтетазы целесообразно считать поглощение кислорода в какой-то заданный интервал времени. При этом полученные значения активности должны быть в прямо пропорциональной зависимости от выходов ПГ $E_{2}$ препаративных биосинтезов, проведенных в совершенно других условиях. Такая зависимость была получена при определении активностей энзимных препаратов (мкмоль $\mathrm{O}_{2} / 3$ мин-мл) в трис-буфере (рис. 3).

Применение трис-буфера позволяет определить активности ПГ-синтетазы в гомогенатах из СПБ в широком диапазоне качества исходного сырья, зависящего от условий сбора и хранения СПБ.

Разработанная методика внедрена на Опытном заводе органического синтеза и биопрепаратов Института химии АН ЭССР при препаративном биосинтезе ПГ $E_{2}$.

\section{ЛИТЕРАТУРА}

1. Лилле Ю., Мянник А., Ягомяги А., Самель Н., Сакс Т. О препаративном биосинтезе простагландинов групп $E$ и $F$ с использованием сиптетазы в виде ацетон-пентанового порошқа, - Изв. АН ЭССР, Хим., 1979, т. 28, № 3 , c. $145-150$, 
2. Лилле Ю., Смородин Е., М арвет Р. О кинетических свойствах простагландин-эндопероксид синтетазы. - Изв. АН ЭССР, Хим., 1979, т. 28, № 2, c. $108-112$.

3. Lowry, O. H., Rosenbrough, N. J., Farr, A. L., Randall, L. J, Protein measurement with the Folin phenol reagent. - J. Biol. Chem., 1951, v. 193 , p. $265-275$.

4. Ягомяги А., Лилле Ю., С акс Т. Препаративное выделение метиларахидоната методом жидкостной колоночной хроматографии. - Изв. АН ЭССР, Хим., 1979 , т. 28 , № 3, с. $151-154$.

5. Hamberg, M., Samuelsson, B. On the mechanism of the biosynthesis of prostaglandins $E_{1}$ and $E_{1 \alpha}$ - - J. Biol. Chem., 1967, v. 242, p. 5336-5343.

6. $\mathrm{S} \mathrm{mith}$, W. L., L a nds, W. E. M. Oxygenation of polyunsaturated fatty acids during prostaglandin biosynthesis by sheep vesicular gland. - Biochem. J., 1972 , v. $11, \mathrm{~N} 17$, p. $3276-3285$.

Ннститут химии

Академии наук Әстонской ССР
Поступила в редакцию $8 / \mathrm{V} 1981$

N. SAMEL, O. LILLE, Lea VALGE, A. MANNIK

\title{
MEETOD JAARA VESIKULAARNÄARMETE PROSTAGLANDIINSUNTETAASI AKTIIVSUSE MÄARAMISEKS
}

On vaadeldud prostaglandiinsüntetaasi sisalduse määramise võimalusi prostaglandiinendoperoksiidsüntetaasi aktiivsuse polarograafilise mõõtmise teel standardselt valmistatud ensüümpreparaatides.

\author{
N. SAMEL, U. LILLE, Lea VALGE, A. MÄNNIK
}

\section{METHOD FOR ESTIMATING PROSTAGLANDIN-SYNTHETASE ACTIVITY IN SHEEP VESICULAR GLANDS}

The polarographic method for estimating prostaglandin endoperoxide synthetase activity in enzyme preparations from sheep vesicular glands has been investigated. The dependence of the activity values on the type of buffer and initiation of reaction is observed. The possibility of using this method for examining the prostaglandin synthetase content in sheep vesicular glands is discussed. 